\title{
Third Sector Organization Interventions in the Public Education System: Do They Contribute to the Quality of Service?
}

\author{
Dafna Beeri Wind \\ Department of Statistics, University of Haifa, Israel.
}

\begin{abstract}
Tightly budgeted government-delivered services are becoming more and more reliant on outsourcing. Thus, public service providers welcome unpaid assistance from private or non-profit organizations. One such strategically important service is education, a service shaping our future societies. External private or nonprofit bodies are actively involved in running these opinion-forming institutes.

The current research is a multi-sector empirical study, designed to examine and estimate the contribution of the Third Sector's involvement in the Public Education System (the Public Sector). The purpose is to examine whether the quality of service and the performance of the education system improve because of this involvement. Two main questions lie at the basis of this research: the firstwhat is the Third Sector's contribution to the results of the Public Education System? The second - is there a difference between the quality of service provided by the Third Sector's organizations and that provided by the Public Education System?
\end{abstract}

\section{Introduction}

In the last three decades, the Israeli Government has received increasing assistance from private organizations and non-profit organizations in providing public services to the population (according to data from 2002, approximately 11\% of all the jobs in the public market are supplied by the Third Sector, derived from the Prime Minister's Office, Department of Policy Planning, 2008). This tendency reduces the Government's involvement to being a mere financial supporter instead of a supplier, or a service provider [22,15]. This activity stems mainly from marketing powers, which are legitimized by the middle and upper classes. The disadvantage of this situation is that the State acts to decentralize its authorities and, as a result, its control is reduced [26].
In the 1990s, this phenomenon expanded and penetrated into educational systems around the world and in Israel (see the following data). Different organizations, such as funds, educational associations and business bodies that were not a part of the official education system, began operating pedagogical programmes (External Learning Programmes - ELP) in the state schools, such as enrichment programmes and launching different projects in collaboration with the local authorities $[14,16,28]$. Third Sector organizations are those that were established voluntarily in order to supply means and services to the education system, stemming from a sense of obligation to the community [1]. Third Sector organizations consist of groups of people, operating to promote values, attitudes, ideas and identities that developed in parallel to the reduction processes of the Public Education System's public service; this occurred in parallel to a rise in the community's demand for quality. Over time, more and more schools began cooperating with these organizations [1,21]. First theories about the appearance of Third Sector organizations in the 1970's, linked this phenomenon to "market failure" or to "Government failure".

The literature reviewed attributes a positive contribution to the Third Sector intervention in schools, and describes a condition in which the schools seek to improve their results by employing organizations outside the public sector [5]. On the other hand, there are various other findings that show that the basis for this intervention is actually related to economic elements [5].

Service Quality is based on three principles: (a) focusing on customers' needs; (b) focusing on service workers' needs; (c) focusing on methods and processes, serving both those customers and workers, carrying out continuous improvements and learning $[25,10]$. Explanations for the changes that occurred in public education systems around the world demonstrate that it was the demand for 
accountability, efficiency and the emergence of regulatory economic requirements and policies that support education as a product with quality service [7]. Accountability increases the level of efficacy and helps to define the criteria for measuring and evaluating performance, which leads to increased motivation and positive impact and better outcomes [20]. When customers confront inadequate or deficient services, they search for alternative suppliers. Such by-passes are not easily obtainable if services are national, such as in the cases of welfare, education or health. The well-to-do may be able to afford privately provided/funded alternative services, but the less affluent have to make do with voluntary bodies, such as philanthropic groups, that are available and willing to help.

Israel, like other OECD member states, has adopted a policy of social welfare and considers itself responsible for ensuring an adequate standard of living for all its citizens [22]. The government delivers services to the entire population in various areas of life such as health, welfare and education. Public service organizations receive government funding, based on tax intakes and budgets. The Third Sector (nonprofit organizations) has become a major force in the economy and in society; bodies such as foundations, associations and businesses started running pedagogical programmes in state schools [19]. More than $40 \%$ of the educational activities of the state education system in Israel are performed by nonprofit organizations rather than by the government. Government regulation is applied in order to protect the population from malpractice, and blocks the intervention of cause-driven bodies in the education system. Regulation is maintained by incentives and sanctions and includes licensing, accreditation, monitoring and controlling.

In general, Third Sector organizations recognize the importance of quality and the need to implement certain quality systems in their processes; however, so far, no attempt has been made to systematically evaluate the quality of their services [6]. Since business profit is not a suitable consideration in the Third Sector, these organizations cannot evaluate their performance by Second Sector (business) criteria alone [3].

\section{Quality perception in organizations}

Quality management is based on systematic process evaluation with emphasis on learning and process improvement [10]. In 1959 the U.S. government was the first to perceive that the world was becoming a different place, a more competitive place with different requirements. It become aware of the differences in products that were made in
Japan, as well as the demand for high quality and reliability in goods and services. As a result, the Military Specification MIL-Q-9858 (Quality Program Requirements) of the U.S. government was established; today, it is considered to be the basic structure for the ISO 9000 series for standards. Although it was designed for the U.S. military industries, its advantages led to the implementation of quality demands by civilian products manufacturers also [33]. In 1987, following an initiative by the European Community, series ISO 9000 for standards was published. In the same years (1950-1980), other quality philosophies appeared such as "Total Quality Management" (TQM), "Total Quality Control" (TQC), Deming's 14 principles for long-term prosperity in organization and more.

The interest regarding the international standard grew quickly and, within a few years, it became a common specification around the world for construction and operation of the quality system in order to improve organizational performance. The transition from industrial quality management to the Public Sector and afterwards to the Third Sector organization took some time. The quality approach gradually moved from the industrial field to the business, service, and public sectors and merged with the management of organizations. The adoption of quality systems was driven not only by the need to improve, but also by ideology $[3,6,10,12]$.

The discussion about "How to improve organizational performance?" in the second and in the third sector has been repeated in the academic literature of associations in England and North America. A wide range of terms and concepts is used to express quality performance and includes concepts such as: efficiency, effectiveness, accountability, standards, capacity (ability), goals, measuring outcomes and evaluation. In general, all kinds of organizations are expected to provide "value for money" and the proof that they do provide it might cause the spread of the "measurement environment" phenomenon [10].

Pressure to improve organization performance emerged from several sources: in the business sector from the organizations themselves as a result of competition for providing better customer service and increasing the profit; in the public sector from the government in order to ensure that they were able to provide the services to the citizens. Since public organizations receive funds and taxes they are committed to perform efficiently, ethically and costeffectively. Organizations began to improve their performance requirements by a variety of approaches that focused on self-evaluation, self-monitoring systems and organizational learning. In general, organizations recognize the importance of quality 
and the need to implement certain quality systems and methods in their processes such as Total Quality Management (TQM), Benchmarking, Balanced Scorecard and Management by Results.

The common element in all of these approaches to improve performance is the systematic attention to detail and strategic framework of value-based policy. Yet we still know little about the internal processes within the associations that adopt and implement approaches to improve performance. Profits are not a suitable consideration in the public sector nor in the third sector; these organizations cannot evaluate their performance by second sector (business) criteria at all. Unlike the private sector, the outcome of the public sector is much harder to measure since the public good is disputed and contains conflicts and contradictions [13].

During the 20th century the perception of the role of the public sector in the West changed. The new concept was known as "value for money" in the UK and "customer-driven government" in the US. offered by business organizations. The common element in these changes was the new perception that saw the citizens as government clients; therefore new demands were made to the public organizations in order to improve services, similar to those provided by business organizations. These concepts have expanded and influenced the public sector reforms in the UK, New Zealand, Australia, USA and Canada [10].

\section{Quality in education}

The public educational system, like other public services organizations, must create new organization patterns and adjustments to changes such as those in the social, political and economic fields [4]. With such economic tendencies, the individual is required to create an overpass to the limitation of public funding by using private organizations as alternative suppliers whose growing appeal is becoming more necessary. Service quality, according to quality perception, must meet the customers' needs; the public service is therefore facing strong and constant pressure to improve its performance and is committed to accountability to the citizens[31].The demand among countries committed to improving schools, providing high-quality education associated with earning capacity, the investment to increasing the quality of education together with the potential of the economic and social systems is becoming more widespread [12]

State schools must have a national curriculum; however, economic changes force them to operate according to business strategies and to develop appropriate educational responses. This approach has forced the education system to convert education into a product; the result of this was the demand for the ability to meet needs with expectations and to implement quality improvements. One of the problems in implementing quality in the education system is the adoption of quality models from the fields of industry and commerce. According to these models, the suppliers are the families, schools, colleges and universities. The input to the system consists of the students, staff and so on. The output will be the added value of new knowledge, tools and capabilities that are necessary for the future societies and organizations. The customers will be the business community, society, students, family and school. The process will be the teaching, student counseling and scientific research [10].

Perceptions of quality in the education systems are diverse; the most common and acceptable definitions of quality in education are: Educational Excellence; a match between the educational output and the needs experience; adjusting the output of the planned purposes of education and skills requirements; preventing mistakes in the educational process, and suitability to the customer educational system expectations [24].

According to the Asian Development Bank (2001), the accepted definition of quality in education is associated with students' achievement levels and the national curricula. Based on this, a comparison is made between students across different countries in different areas such as maths, reading comprehension and science.

In this article, quality is defined as a measure applying to transactions among various bodies. The level of quality is high if the needs of all the bodies are met. Quality in the education system will detect the full potential of the individual according to the needs of all parties involved, students, parents, community, those existing and those in the future.

\section{Measuring education performance}

The human capital approach to measure the output of the education system prefers to focus on the cost of the investment or the number of students as an indicator of the quality of education output. This approach is based on the perception that students' time invested in studies represents the educational process input and not the output. This perception shows the difficulty of quantifying the elements of educational process that can produce a greater outcome [18]. In general, the accepted indicators used to measured the education systems performance are in terms of earning capacity or production capacity, but this observation creates a partial or an incomplete picture. The benefits of 
schooling are beyond the students' needs; they can also positively affect their future social values as well as create their future social agenda of life. Thus, the educational assessment should include whatever can contribute to increase the options for production: reducing costs and making more resources available; increasing the possibilities of welfare and influencing the social consciousness [30]. OECD defines education system output by two components: activities/processes and the quality adjusted by implementation [27]. In 1997, the OECD launched an international research and evaluation programme of students; conducted in schools every three years, it was called PISA. Another familiar international test to measure educational achievement in mathematics and science is called TIMSS (Third International Mathematics and Science Study). This test is conducted every four years by IEA (International Association for the Evaluation of Educational Achievement). An additional well-known international test conducted by IEA is the PIRLS (Progress in International Reading Literacy Study). There are many other accepted international tests in education designed to understand the state of affairs relating the investment (input) in education to the performance (output) of education. The problem in most of these kinds of tests is that they measure only the scholastic achievements and not other important indicators such as values or the professional development of the market workforce.

The public education system in Israel has created its own indicators in order to determine the scholastic goals, and to control and monitor the learning process called MEIG tests (Measures of Efficiency and Interscholastic Growth). The MEIG test is administered once every four years and consists of two parts: a system test for students' achievements in four fields (native language, mathematics, English and science) and climate questionnaires to examine students' motivation to study, teacher-student relationships, violence between students and teachers teamwork. The climate questionnaire is designed to illustrate a comprehensive picture about the ambience and the processes that are taking place in the school.

\section{Methods}

Assessment processes in Third Sector organizations operating in the public education system should include graduates' output parameters such as knowledge, skills, values, behaviour, learning abilities, responsibility, and accountability.

We measured the quality of process in schools and in Third Sector organizations involved in some of the schools sampled. We based our measuring processes on well-proven published research concentrating on the topics and fields of quality, education and Third Sector studies. Well-known frameworks used were the Baldrige Performance Excellence Award for education systems [2] and the SERVQUAL model [32]. We measured output performance of the schools based on several sources: the Logic Model for measuring the performance of public and Third Sector organizations [23], the Israeli Ministry of Education's Indicators and its index, "Measures of Efficiency and Interscholastic Growth", measured per school.

We devised a model that evaluates the performance parameters and quality culture of the schools and the intervening bodies.

The research tool we used for gathering the data and for the statistical processing was a questionnaire that measured the seven independent variables of quality of service as they appear in several literary research sources: (1) vision, (2) leadership, (3) strategy, (4) culture, (5) manpower, (6) focusing on the client, and (7) organizational learning. Output (success) dependent variables were the three sources for measuring school scores: (1) scores according to teachers' reports, (2) parents' satisfaction with the school, and (3) the results of the school's MEIG tests. In order to complete the data, we held semistructured interviews with CEOs and General Managers of associations and funds. These interviews were based on the same seven variables of quality of service (Figure 1).

The research includes three different populations: teachers from 30 secular state schools from the Haifa District alone (380 teachers); the Third Sector's population (interviews with 15 associations' General Managers and CEOs and questionnaires given to 67 volunteers/employees of the Third Sector), and the parents of students who attend 20 of the schools that participated in the research (205 parents).

Cronbach's alpha $(\alpha)$ testing of the teachers' questionnaires $(n=380)$ using SPSS software was in the range of .78 to .92 . Cronbach's alpha $(\alpha)$ testing of the parents' questionnaires $(n=205)$ was .92 . Cronbach's alpha $(\alpha)$ testing of the questionnaires given to 67 volunteers/employees of the Third Sector was in the range of .63 to .94 .

The main procedures we conducted included: exploratory factors analysis for the research questionnaire; testing correlations between the research variables; comparing averages by using $\mathrm{t}$ tests in order to find differences between the Public and the Third sectors, regression analysis to find models for forecasting, and analysis of field interviews that were conducted with representatives of the associations. 
In our extensive data analyses we assessed the direct effect of schools' operational parameters on students' results; the direct effect of an intervening body's operational parameters on students' results; and the effect of the intervening body's operational parameters, mediated by the school's operational parameters, on students' results.
We compared and analyzed results in order to assess whether society was receiving a better quality education service due to the intervention of Third Sector bodies in the state schools.

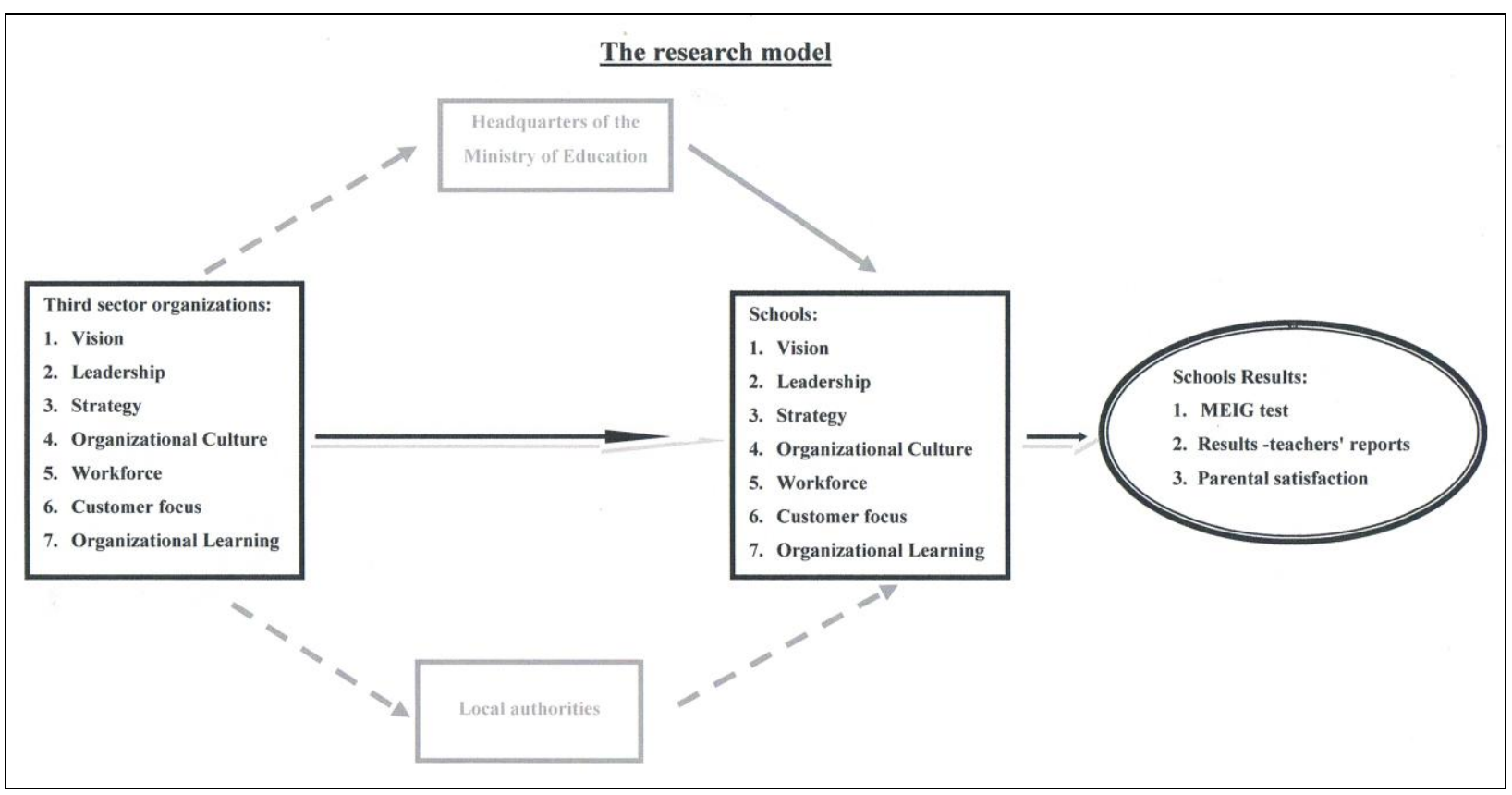

Figure 1. The research model

\section{Findings}

The main findings of the research were:

(a) We found "external learning programmes" operating in every school. Furthermore, in all the schools that were modelled, the number of intervening factors, the "external learning programmes" were at least 3-5 per school (Figure 2).

Number of "external learning programmes" in schools

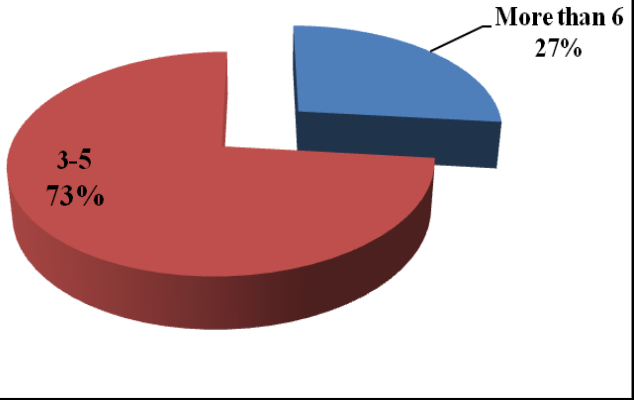

Figure 2. Number of "external learning programmes" in schools. (b) Analysis of the data provides empirical proof that the increase in externally provided classes does not contribute to a rise in the school's results, but slightly and significantly the opposite ( $\mathrm{r}=-0.548$; $\mathrm{p} \leq 0.0001)$. In all cases where more than six "external learning programmes" were reported to be operating in a school, the findings showed low MEIG results. The relation between the "external learning programmes" variable and the MEIG variable is significant, strong and negative (Figure 3).

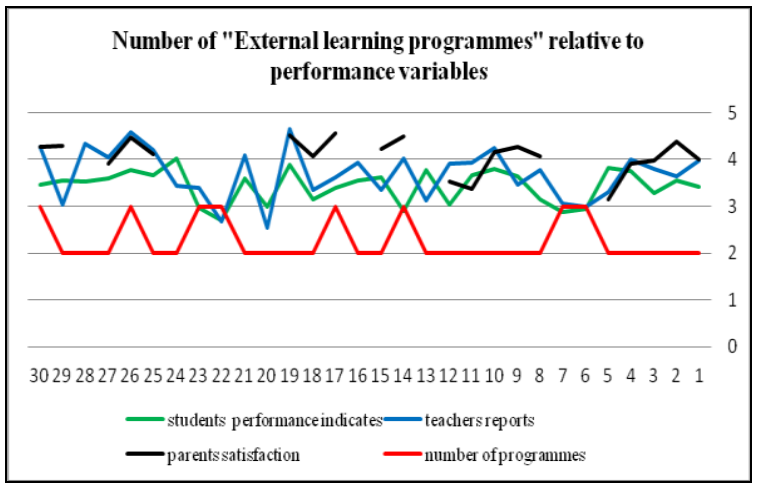

Figure 3. Number of "external learning programmes" relative to performance variables 
(c) t-test of the three sources of school outcomes: (1) scores according to teachers' reports, (2) parents' satisfaction with the school, and (3) the results of the school's MEIG, regarding the number of "external learning programmes" found significant mean differences between the number of "external learning programmes" in the school and parental satisfaction. This finding demonstrates that the more additional "external learning programmes" exist in a school, the happier the parents. It seems that parents are aware of additional Third Sector contributions to the school and respond to that with satisfaction ( $p$ $\leq 0.0001 ; \mathrm{t}=-15.04$ ) (Figure 4).

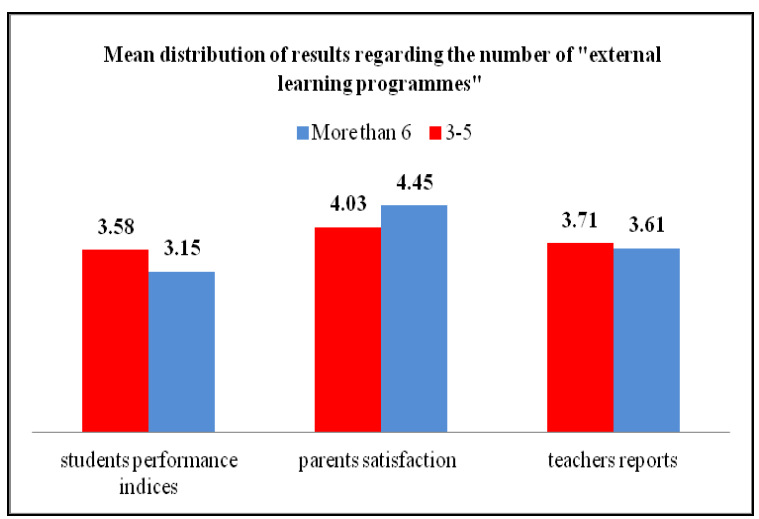

Figure 4. Mean distribution of results regarding the number of "external learning programmes".

(d) The schools' quality of service is higher than the quality of service of the Third Sectors organizations operating within the schools. In other words, the Third Sector organizations have no advantage in terms of the quality of service they supply to clients.

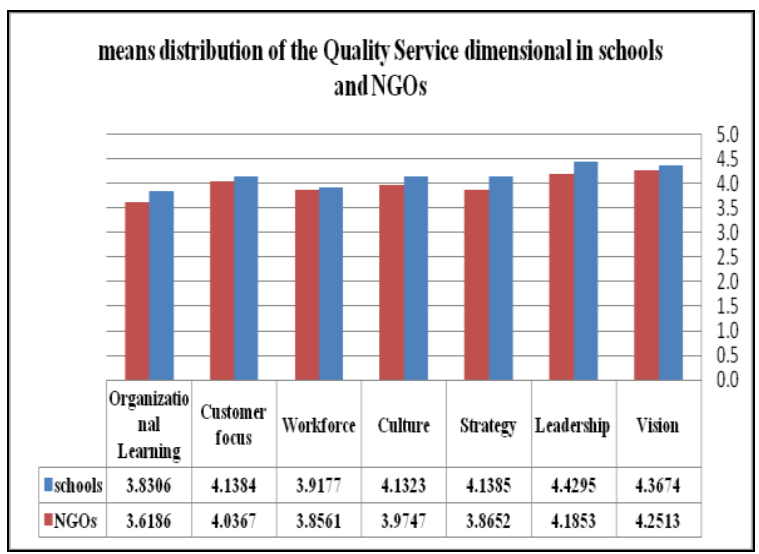

Figure 5. Mean distribution of the Quality Service dimensional in schools and NGOs

Three of the seven quality of service variables -leadership, strategy and culture -- measured in the schools and the associations were found higher in the schools than in the associations themselves, i.e. there was a positive gap in favour of the education system (Figure 5).

(e) The number of additional study programmes that undergo no screening or content examinations by the Ministry of Education's Pedagogic Secretariat exceeds seventy per cent. The education system has a privatization policy but it does not have a regulation policy and most of the additional study programmes exist without a professional framework or evaluation. "The schools do not have the ability to study the impact of these programmes and to derive from them standards for success or improvement. In addition, the education system is unable to create a complete comparative picture regarding the quality of the activities, the quality of the teaching materials and the manpower" [28].

(f) $40 \%$ of the associations and funds (six of the fifteen associations that participated in the study) declared that the workforce in the teaching programmes has no pedagogical qualification or training. Moreover, there are no agreed or determined prerequisites of pedagogical qualification in the workforce they recruit. Two of the fifteen CEOs and General Managers that we interviewed admitted that they do not see the pedagogical qualification as an advantage parameter. On the contrary, they see the pedagogical qualification as a disadvantage since they are concerned about teaching burnout.

\section{Conclusions}

The current study examined several major points: the prevailing work policy existing between the public sector (First Sector) and the voluntary sector (Third Sector); the contribution of the two sectors (First and Third) to the service quality of the education system, and evaluation of the performance of schools where there is an intervention of Third Sector organizations.

Organizations that outsource processes and are also committed to quality standards require the upholding of those standards by the external suppliers. This leads to the recognition of the importance of performing quality evaluation of the external factor (outsourcing) involved. According to the research findings, the phenomenon of organizations entering schools stems from two main reasons: firstly from the fact that parents are a powerful factor on the school board and require the system (the school board) to provide services to the minority groups. The second reason is well known and has been studied in the past. It represents the relationship between school principals and Third 
Sector organizations regarding the improvement of schools and their performance [28,29].

The official policy of the Ministry of Education does not allow the entry of organizations into the school system without screening. However, there is a lack of control over what is happening in schools. Consequently, Third Sector organizations penetrate the system without the approval of the headquarters of the Ministry of Education and contrary to its policy. A conflict arises from this situation due to the desire of the education system to reduce the involvement in the provision of services by Third Sector organizations, whilst also maintaining its hold on control and supervision [9].

The current study describes the relationship and the partnership policy of the two sectors. The sources to describe this partnership were the headquarters of the Ministry of Education, the department of the Local Authority, the schools and the CEOs of NGOs. The findings describe a complex picture of the relationship between the Third Sector and the Public Sector. Non-profit organizations use three different ways to enter the education system: through the headquarters of the Ministry of Education, through Local Authorities and through school principals. Non-profit organizations entering through the headquarters of the Ministry of Education create long-term structure cooperation that includes policy. This collaboration is designed to change the organizational structure at the Ministry of Education and replace the public sector by using the third sector to supply the specific services. In this case, the Ministry of Education has set a policy and labour contracts for working with the intervening organizations.

Organizations that enter the education system through the local authorities and schools provide services in addition to those of the government. The local authorities see the importance of fostering a quality education system since it poses a strong migration factor for quality population.

Organizations that enter through schools, according to our research findings, result from two main reasons: first, the fact that parents exert a powerful pressure on the school board as well as on the school principal to provide services to the minority groups. Second, the school principal troubled by the students' achievements choose to operate educational programmes by external organizations.

We found confirmation of our findings in a similar study from England which examined the outcome of the collaboration between the private sector (business) and the public education system [11]. The study found that the students' achievements from using business organizations as outsource operations for educational programmes were weak. An important finding of the study was the identification of the starting point as a success indicator of the contribution for performance. When the preliminary condition of the education system was inferior, the external intervention produced better result by the students. Once the average results of students were achieved, the contribution to their performance became marginal and low.

The research supports the reasoning opposing the privatization of the national education system, and opposes the claims about the ineffectiveness of school management. Despite the many complaints about the State school system, the current study indicates that some of the quality of service variables exhibited better performances in the public sector (the schools) rather than in the Third Sector. The observations we conducted showed that schools indeed had vision, a sense of purpose, work procedures, regular meetings, held dialogues with parents, etc. Third Sector bodies were less structured as far as mission, vision, procedures, methods and knowledge management were concerned. The major problem in relation to the connection between the two sectors is the lack of regulation and monitoring of the interface processes and the content of the additional study programmes. We found that the involvement of the Third Sector did not influence the performance of the education system in a definite, positive manner and it may, in fact, have harmed the system's regular conduct.

The practical implications of these findings suggest that there is a need to re-examine those aspects of the extensive procedures of privatization that are partly disputed and are taking place inside the education system.

\section{References}

[1] Anheier, H. "What Kind of Nonprofit Sector, What Kind of Society? Comparative Policy Reflections", American Behavioral Scientist, Vol. 52, (2009) pp. 10821094.

[2] Baldrige national quality program, Education Criteria for Performance Excellence (2011-2012).

[3] Benz, M. "Not for the Profit, but for the Satisfaction? Evidence on Worker Well-Being in Non-Profit Firms", International Review for Social Sciences, Vol. 58, No. 2, (2005) pp.155-176.

[4] Ben-Elia, v. "The Education Citizenship in Israel: deregulation, democratization and increased responsibility". Floersheimer Research Policy Institute Ltd., Jerusalem. Vol.8, pp. (2000) 42-43 (Hebrew) 
[5] Berkovich, I., Foldes, V., J., "Third Sector Involvement in Public Education: the Israeli case", Journal of Educational Administration, Vol. 50 Iss: 2, (2012) pp.173 187.

[6] Cairns, B. Harris, M. Hutchison, R. Tricker, T. "Improving Performance? The Adoption and Implementation of Quality Systems in UK Nonprofits", Management \& Leadership, Vol. 16 No.2, (2005) pp.13551.

[7] Deming, W. E."The New Economics For Industry, Government, Education", Ch. 5. Second Edition. The MIT Press (2000).

[8] Donnelly, M. Wisniewski,M. Dalrymple, J.F. Curry, A.C. "Measuring service quality in local government: the SERVQUAL approach". International Journal of Public Sector Management. Vol. 8, (1995) PP. 15-20.

[9] Eden, D. "Whose responsibility is it?" The Third Sector and the Educational System in Israel. International Review of Education, Vol. 58, Issue 1,(2012) pp. 35-54.

[10] Evans, J. R. and Lindsay, W. M., "The Management and Control of Quality", Fifth Edition; South-Western College Publishing (2006).

[11] Farnsworth, K. "Business in education: a reassessment of the contribution of outsourcing to LEA performance". Journal of Education Policy, Vol.21 (2006) Issue.4, pp. 485-496.

[12] Hanushek Eric A. "Why Quality Matters in Education. Finance and development", Vol.42 (2005) Issue no.2.

[13] Heintzman, R. Marson, B. (2005) People, service and trust: is there a public sector service value chain? International Review of Administrative Sciences 2005; Vol.71; 549-575.

[14] Gidron, B. "Study of the Third Sector and Civil Society in Israel: History and Current Situation". The Third Sector and Civil Society in Israel Vol.1 (2007) pp. 817.

[15] Gidron, B. Bar, M. Katz, H. "Third Sector in Israel 2000: Sector Roles". The Israeli Centre for Third Sector Research, Ben-Gurion University of the Negev (2000).

[16] Gidron, B. Bar, M. Katz, H. "The Third Sector, the Welfare State and Civil Society". Kibbutz Meuchad Press (2003).

[17] James, p. "Voluntary sector outsourcing: A reflection on employment-related rationales, developments and outcomes", International Journal of Public Sector Management, Vol. 24 Issue: 7, (2011) pp.684 - 693.

[18] Jorgenson, W.D. Fraumeni, B.M. Christian, M.S. "A Human Capital Approach to Measuring the Output of Education for the U. S.", Session 5- OECD.org (2006).
[19] Katz, H. Gidron, B. \& Limor, N. "The Third Sector in Israel - Characteristics, Structure and Policies Towards It", Published in Civil Review, (2009), 3.

[20] Kellaghan, T. Greaney,V. "Using assessment to improve the quality of education", UNESCO: International Institute for education planning, (2001) pp. 22-27.

[21] Kendall, J. "Terra Incognita: Third Sector and European Policy Process", Handbook on Third Sector Policy in Europe. Part 1,(2009) pp. 3-20.

[22] Mano, R. "Manage or lead, the fundamentals of management, vision and success in non-profit organizations in Israel". Pardes Publishing (2009).

[23] Poister, T.H. "Measuring performance in public and nonprofit organizations". Chapter Three. San Francisco, CA : Jossey-Bass,(2003) pp.35-57.

[24] Sahney, S., Kumar Banwet,D., Karunes,S., "Enhancing quality in education: application of quality function deployment - an industry perspective", Work Study, Vol. 52 (2003) Iss: 6 pp. 297 - 309.

[25] Schneider, B. and D. Bowen, "Winning the Service Game", Boston: Harvard Business School Press (1995).

[26] Savirsky, B. Dagan-Buzaglo,V. "Differentiation, Inequality and Weak Leadership: The State of Affairs of Israeli Education". Adva center for information on equality and social justice (2009).

[27] Schreyer, P. "Towards Measuring the Volume Output of Education and Health Services: A Handbook". OECD Statistics Working Papers, 2010/2, OECD

Publishing. doi: 10.1787/5kmd34g1zk9x-en (2010).

[28] Veinhaber, B. "The Third Sector and Business Philanthropy in Education". The centre of possessions, Issue No.2 Education Entrepreneurship, Beit Berl (2008).

[29] Young, D. R. "Alternative Models of GovernmentNonprofit Sector Relation: Theoretical and International Perspective". Nonprofit and Voluntary Sector Quarterly, Vol.29, no.1 (2000), pp.149-172.

[30] Weisbrod, B.A. Education and Investment in Human Capital. The Journal of Political Economy, Vol. 70 (1962), No. 5, Part 2, pp. 106-123

[31] Wisniewski, M. "Using SERVQUAL to assess customer satisfaction with public sector services". Managing Service Quality Vol.11 (2001) PP. 380-388.

[32] Zeithaml, V. A., Parasuraman and Leonard L. Berry, "Delivering Quality Service", New York: The Free Press (1990).

[33] Zane D., Valdis J., "Quality Management System as a Tool for Corporate Development and Competitiveness Increase" Scientific Journal of Riga Technical University Sustainable Spatial Development Vol.3 (2011) p. 71-76. 